Pak. j. sci. ind. res. Ser. A: phys. sci. 201255 (2) 72-79

\title{
Study of Interaction Between Zinc(II) and Aspartic Acid Using Cyclic Voltammetry
}

\author{
Muhammad Elius Hossain, Muhammad Mahmudul Hasan, \\ Mohammad Al-Mamun and Mohammad Qamrul Ehsan* \\ Department of Chemistry, University of Dhaka, Dhaka-1000, Bangladesh
}

(received January 12, 2011; revised June 1, 2011; accepted June 7, 2011)

\begin{abstract}
The redox behaviour of $\mathrm{Zn}$ (II) and $\mathrm{Zn}$ (II) in presence of aspartic acid have been studied by cyclic voltammetric (CV) method within the potential window of 200 to $1400 \mathrm{mV}$ at glassy carbon electrode (GC) combined with $\mathrm{Ag} / \mathrm{AgCl}$ reference electrode and Pt-wire counter electrode. Due to the interaction of $\mathrm{Zn}$ (II) with the ligand, the peak current and peak positions are changed. After interaction the cathodic peak shifts to right and anodic peak to left. The interaction was investigated in different supporting electrolytes like $\mathrm{KCl}$ and $\mathrm{NaClO}_{4}$. The effect of $\mathrm{pH}$ on the interaction was studied using acetate buffer of different $\mathrm{pH}$. The peak current ratio $\left(\mathrm{i}_{\mathrm{pa}} / \mathrm{i}_{\mathrm{pc}}\right)$ and peak potential separation demonstrates that, before and after interaction between metal and ligand the $\mathrm{Zn}$ (II) / Zn (0) system shows quasi-reversible behaviour.
\end{abstract}

Keywords: cyclic voltammetry, redox reaction, aspartic acid, glassy carbon electrode, quasi-reversible

\section{Introduction}

Amino acids serve crucial functions essentially in all biological processes. They function as catalysts; transport and store other molecules such as oxygen; provide mechanical support and immune protection. Aspartic acid is an acidic amino acid. It plays an important role as general acid in enzyme active centers, as well as in maintaining the solubility and ionic character of proteins. Proteins in the serum are critical in maintaining the $\mathrm{pH}$ balance in the body. It is largely the charged amino acids that are involved in the buffering properties of proteins. It serves as an excitatory neurotransmitter in the brain and is an excitotoxin. As a neurotransmitter, aspartic acid may provide resistance to fatigue, and thus, leads to endurance, although the evidence to support this idea is not strong (Zeigler et al., 1996).

Zinc participates in all major biochemical pathways and plays multiple roles in the perpetuation of genetic material, including transcription of DNA, translation of RNA, and ultimately cell division. Zinc is the most important of all trace elements involved in human metabolism. More than one hundred specific enzymes require zinc for their catalytic function (Nelson et al., 2000). Therefore, knowledge about the redox behaviour of $\mathrm{Zn}$ in the presence of ligand at different $\mathrm{pH}$ values is very important.

The cyclic voltammetric technique is extremely popular in chemical research, because it can provide useful *Author for correspondence; E-mail:mqehsan@yahoo.com, mdqehsan@gmail.com information about redox reactions in an easily obtained and interpreted form. The electrochemical study of interaction between different metal ions and biologically important ligands including amino acids have been studied in our laboratory and other groups (Naseem et al., 2008; Rahman et al., 2007, Shaikh et al., 2006; Shaikh et al., 2005; Ismat-Ara et al., 2003; Kabir et al., 2002; Khan et al., 1999; Nabi et al., 1999; Rahman et al., 1998a and b). Investigation of metal-amino acid interaction using cyclic voltammetry is rare therefore, we investigated and presented the redox behaviour of $\mathrm{Zn}$ (II) and interaction of zinc with aspartic acid (using cyclic voltammetry) in various electrolytes at glassy carbon (GC) electrode.

\section{Materials and Methods}

Reagents and solutions. The buffers were prepared using sodium acetate (MERCK) and acetic acid (SigmaAldrich Laborchemikalien, $\mathrm{GmbH}$ ). Other chemicals used in this experiment were: zinc chloride (MERCK), aspartic acid (BDH Chemicals Ltd.), potassium chloride (MERCK, Germany), sodium perchlorate monohydrate (MERCK).

Equipments. The current-voltage measurements were performed with an Epsilon Electroanalyser of Bioanalytical System, Inc. USA. The $\mathrm{pH}$ of the experimental solutions was measured by Orion $2 \mathrm{Star}$ (Thermo Electron Corporation) $\mathrm{pH}$ meter. A voltammetric cell (threeelectrode electrolysis system) made of borosilicate glass was used in this work. The glassy carbon electrode was 
used as working electrode, $\mathrm{Ag} / \mathrm{AgCl}$ (satd. $\mathrm{KCl}$ ) as reference electrode and $\mathrm{Pt}$ wire as counter electrode. The purging was done by $99.99 \%$ pure nitrogen (BOC, Bangladesh) and the stirring of the solutions was done by an AGE (Velp Scientifica) magnetic stirrer.

Prior to use, the glassy carbon electrode was polished with fine alumina powder on a polishing cloth wet with deionized water for about $5 \mathrm{~min}$. After polishing, the electrode was rinsed with a plenty of deionized water and was wiped-off with a clean tissue paper. The reference and counter electrodes were also rinsed with a plenty of deionized water before use.

\section{Results and Discussion}

Redox behaviour of $\mathrm{Zn}$ (II) and $\mathrm{Zn}$ (II) in presence of aspartic acid were investigated in $0.1 \mathrm{M} \mathrm{KCl}, 0.1 \mathrm{M}$ $\mathrm{NaClO}_{4}$ and acetate buffer of different $\mathrm{pH}$ using cyclic voltammetric technique within the potential window from $200 \mathrm{mV}$ to $1400 \mathrm{mV}$ at glassy carbon electrode.

Redox behaviour of free $\mathrm{Zn}$ (II) in $0.1 \mathrm{M} \mathrm{NaClO}$. The CVs of $2 \mathrm{mM} \mathrm{ZnCl}_{2}$ in $0.1 \mathrm{M} \mathrm{NaClO}_{4}$ and that of the electrolyte, $0.1 \mathrm{M} \mathrm{NaClO}_{4}$ at $50 \mathrm{mV} / \mathrm{s}$ are shown in Fig. 1. From the figure it is observed that for the $\mathrm{Zn}(\mathrm{II}) / \mathrm{Zn}(0)$ system shows two step redox behaviour. There is a cathodic peak at potential $-1096.0 \mathrm{mV}$ and an anodic peak at potential $-854.7 \mathrm{mV}$. The supporting electrolyte does not show any peak.

Scan rate effect in the $\mathrm{CV}$ of free $\mathrm{Zn}$ (II). A series of cyclic voltammograms of $2 \mathrm{mM} \mathrm{ZnCl}_{2}$ in $0.1 \mathrm{M} \mathrm{NaClO}_{4}$ electrolyte at different scan rates are shown in Fig. 2. The current-potential data, peak potential separation, peak current ratio of the voltammograms of $\mathrm{Zn}$ (II) at different scan rates are recorded in Table 1.

The peak potential separation $(\Delta \mathrm{E})$ increases with scan rate (Table 1 and Fig. 3). This may due to the slow charge transfer kinetics or ohmic potential (iR) drop (Zhang and Anson, 1992; Wopschall and Shain, 1967a and $b$ ). The peak current of both cathodic and anodic

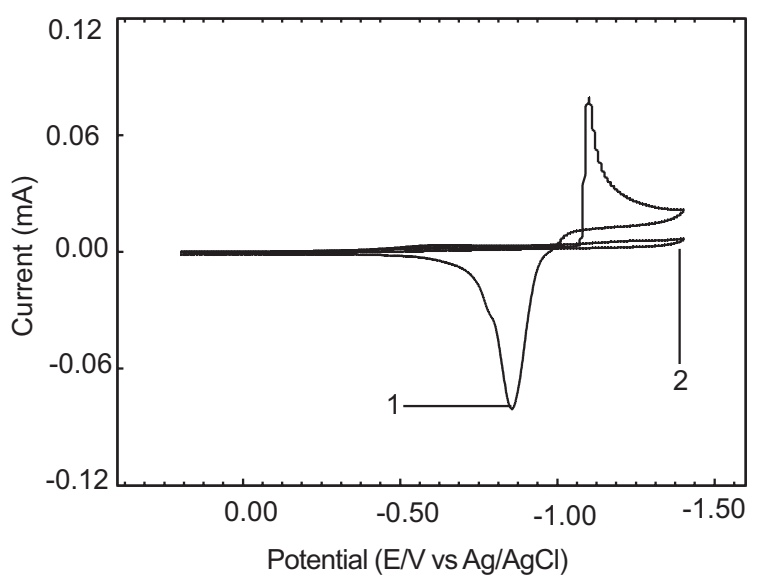

Fig. 1. $\mathrm{CVs}$ of (1) $2 \mathrm{mM} \mathrm{ZnCl}_{2}$ in $\mathrm{NaClO}_{4}$ and (2) blank $\mathrm{NaClO}_{4}$ at $50 \mathrm{mV} / \mathrm{s}$.

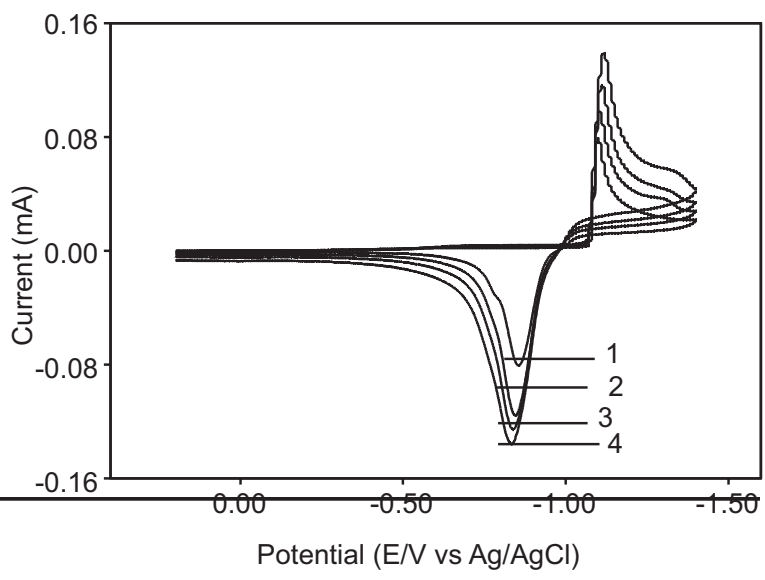

Fig. 2. $\mathrm{CVs}$ of $2 \mathrm{mM} \mathrm{ZnCl}_{2}$ in $0.1 \mathrm{M} \mathrm{NaClO}_{4}$ at different scan rates (1) 50, (2) 100, (3) 150, (4) $250 \mathrm{~V} / \mathrm{s}$.

Table 1. Current-potential data, peak potential separation, peak current ratio of the voltammograms of $2 \mathrm{mM}$ $\mathrm{ZnCl}_{2}$ in $0.1 \mathrm{M} \mathrm{NaClO}_{4}$ at different scan rates

\begin{tabular}{|c|c|c|c|c|c|c|c|}
\hline $\begin{array}{l}\text { Scan rate } \\
\mathrm{V} / \mathrm{s}\end{array}$ & $\begin{array}{l}\text { SQRT of } \\
\text { scan rate } \\
\mathrm{v}^{1 / 2}\end{array}$ & $\begin{array}{l}\text { Anodic peak } \\
\text { potential } \\
\mathrm{E}_{\mathrm{pa}} \text { Volt } \\
(-)\end{array}$ & $\begin{array}{l}\text { Cathodic peak } \\
\text { potential } \\
\mathrm{E}_{\mathrm{pc}} \text { Volt } \\
(-)\end{array}$ & $\begin{array}{l}\text { Anodic peak } \\
\text { current } \\
\mathrm{i}_{\text {pa }} \mathrm{mA} \\
(-)\end{array}$ & $\begin{array}{l}\text { Cathodic peak } \\
\text { current } \\
\mathrm{i}_{\mathrm{pc}} \mathrm{mA} \\
(+)\end{array}$ & $\begin{array}{l}\text { Peak potential } \\
\text { separation } \\
\Delta \mathrm{E}=\mathrm{E}_{\mathrm{pa}} \sim \mathrm{E}_{\mathrm{pc}} \\
\text { Volt }\end{array}$ & $\begin{array}{l}\text { Peak current } \\
\text { ratio } \\
\mathrm{i}_{\mathrm{pa}} / \mathrm{i}_{\mathrm{pc}}\end{array}$ \\
\hline 0.050 & 0.2236 & 0.8547 & 1.1000 & 0.0800 & 0.0773 & 0.2453 & 1.0349 \\
\hline 0.100 & 0.3162 & 0.8413 & 1.1050 & 0.1160 & 0.0967 & 0.2637 & 1.1996 \\
\hline 0.150 & 0.3872 & 0.8369 & 1.1090 & 0.1290 & 0.1146 & 0.2721 & 1.1257 \\
\hline 0.250 & 0.5000 & 0.8324 & 1.1180 & 0.1400 & 0.1364 & 0.2856 & 1.0264 \\
\hline
\end{tabular}


peaks increase with increasing $\mathrm{v}^{1 / 2}$, (Table 1), indicating that the process is adsorption controlled. The peak current ratio $\left(\mathrm{i}_{\mathrm{pa}} / \mathrm{i}_{\mathrm{pc}}\right)$ is found more than unity, which implies the system may be quasi-reversible (Rossiter and Hamilton, 1986; Bard and Faulkner, 1980).

The peak potential increases linearly with $\log v$ (Fig. 4), while Fig. 5 shows the decrease in peak current function $\mathrm{i}_{\mathrm{p} / \mathrm{v}} / 2$ with increasing scan rate $v$. This fact further confirms the adsorption process at the GC electrode surface (Christian, 2004; Bard and Faulkner, 1980; Wopschall and Shain, 1967a and b). A plot of log i vs. $\log v$ (Fig. 6) is linear, which again indicates that the process is diffusion controlled (Salimi and Ghadermazi, 2002; Mascus et al., 1996). The peak current is controlled by both charge transfer and mass transport. The ratio between peak currents for the redox couple is greater than unity. This behaviour indicates that the system shows quasi-reversible behaviour.

Redox behaviour of $\mathrm{Zn}$ (II) in presence of aspartic acid in $0.1 \mathrm{M} \mathrm{NaClO}_{4}$. The redox behaviour of $\mathrm{Zn}$ (II) and $\mathrm{Zn}$ (II) in presence of aspartic acid are shown in Fig. 7. They exhibit one cathodic and one anodic peak due to $\mathrm{Zn}(\mathrm{II}) / \mathrm{Zn}(0)$ system. The cathodic and anodic peak position of the voltammogram of coordinated $\mathrm{Zn}$ (II) moves towards right and left, respectively with respect to that of uncoordinated $\mathrm{Zn}$ (II). Moreover the intensity of the peaks has been reduced. This behaviour confirms the interaction between $\mathrm{Zn}$ (II) and aspartic acid.

Scan rate effect in the $\mathrm{CV}$ of $\mathrm{Zn}$ (II) in presence of aspartic acid. A series of cyclic voltammograms of

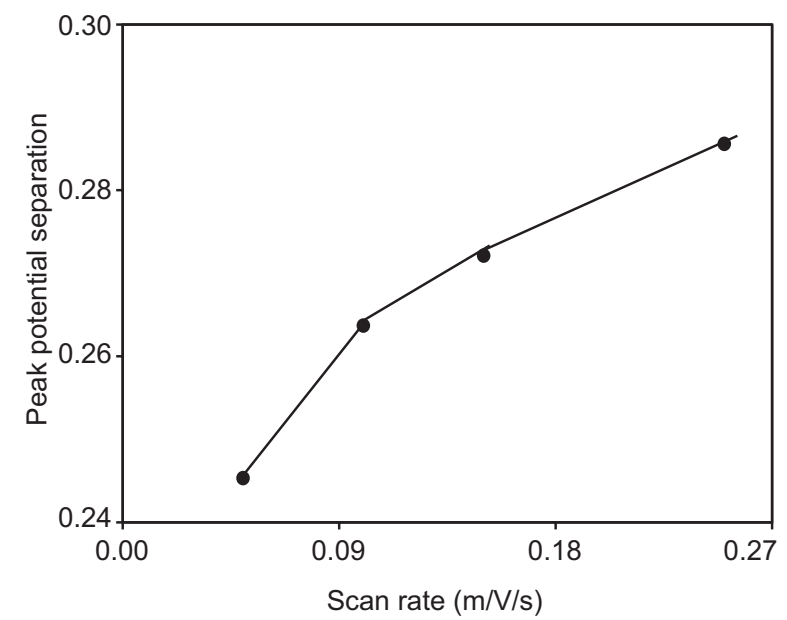

Fig. 3. Variation of peak potential separation with scan rate.

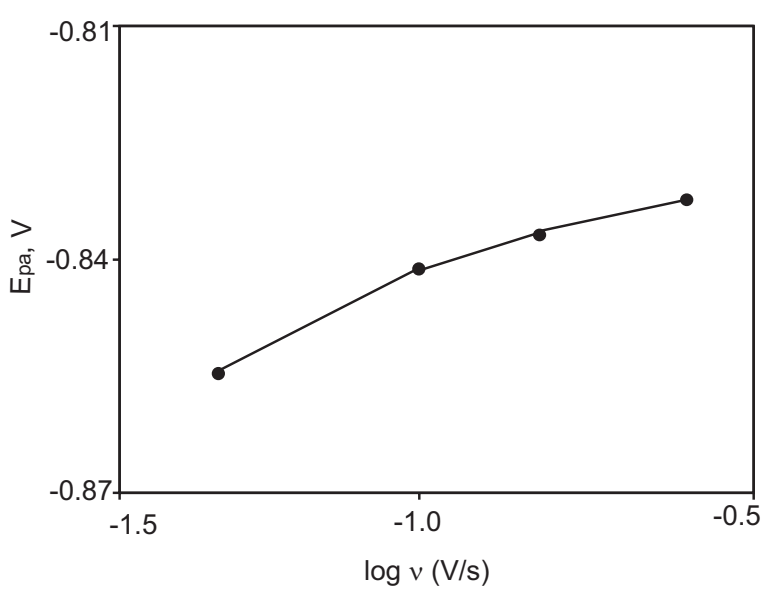

Fig. 4. Plot of peak potential vs $\log v$ for the oxidation peak.

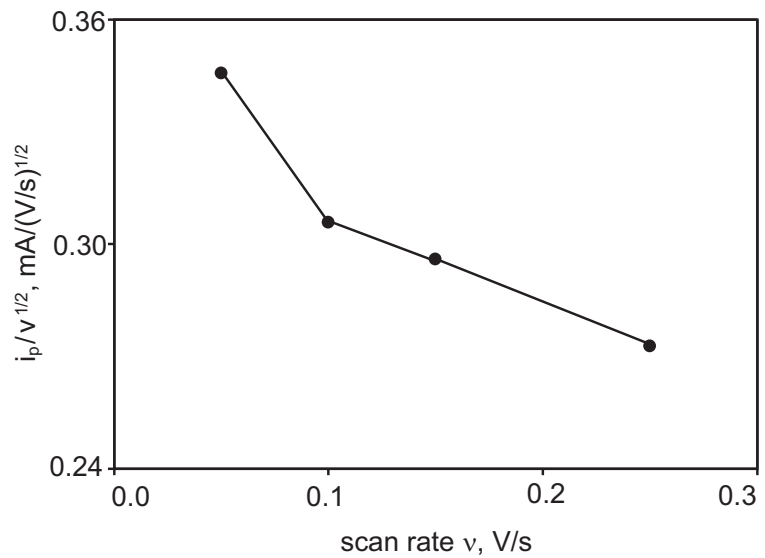

Fig. 5. Variation peak current function $\left(i_{p} / v^{1 / 2}\right)$ with scan rate.

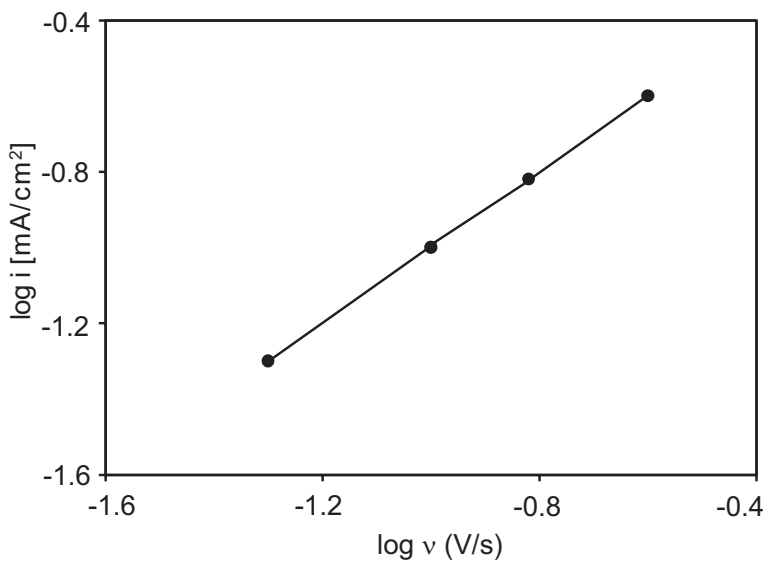

Fig. 6. Plot of $\log \mathrm{i}$ vs $\log v$ for $2 \mathrm{mM} \mathrm{ZnCl}_{2}$ in $0.1 \mathrm{M} \mathrm{NaClO}_{4}$. 
$\mathrm{Zn}(\mathrm{II})$ in presence of aspartic acid in $0.1 \mathrm{M} \mathrm{NaClO}_{4}$ at different scan rates are shown in Fig. 8. The currentpotential data, peak potential separation, peak current ratio of the voltammograms of $\mathrm{Zn}$ (II) in presence of aspartic acid at different scan rates are recorded in Table 2.

Due to interaction of $\mathrm{Zn}$ and ligand the peak position and intensity of the peaks are modified, but the nature remain the same. Fig. 8, demonstrates that, with the increase of scan rate the cathodic peaks shift towards more negative potentials and the anodic peaks shift towards less negative potentials. The peak potential separation $(\Delta \mathrm{E})$ increases with scan rate (Table 2 and Fig. 9). This may be due to the slow charge transfer kinetics or ohmic potential (iR) drop (Zhang and Anson, 1992; Wopschall and Shain, 1967a and b). The redox process is adsorption controlled and quasi-reversible (like the free $\mathrm{Zn}$ ) as indicated by the increase of both cathodic and anodic peaks with $v^{1 / 2}$, and peak current

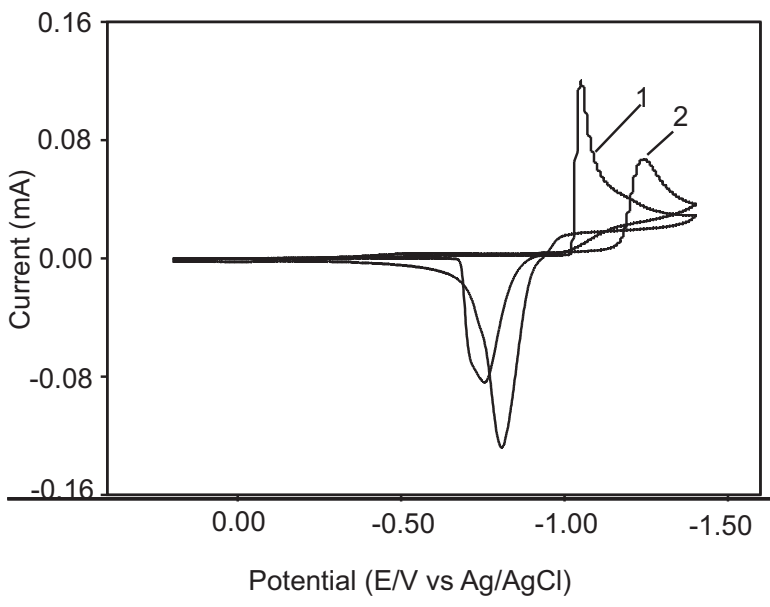

Fig. 7. $\mathrm{CVs}$ of (1) $3 \mathrm{mM} \mathrm{ZnCl}_{2}$ and (2) $3 \mathrm{M} \mathrm{ZnCl}_{2}$ with $3 \mathrm{mM}$ Asp in $\mathrm{NaClO}_{4}$ at $50 \mathrm{mV} / \mathrm{s}$. ratio $\left(\mathrm{i}_{\mathrm{p} a} / \mathrm{i}_{\mathrm{pc}}\right)$ (Rossiter and Hamilton, 1986; Bard and Faulkner, 1980).

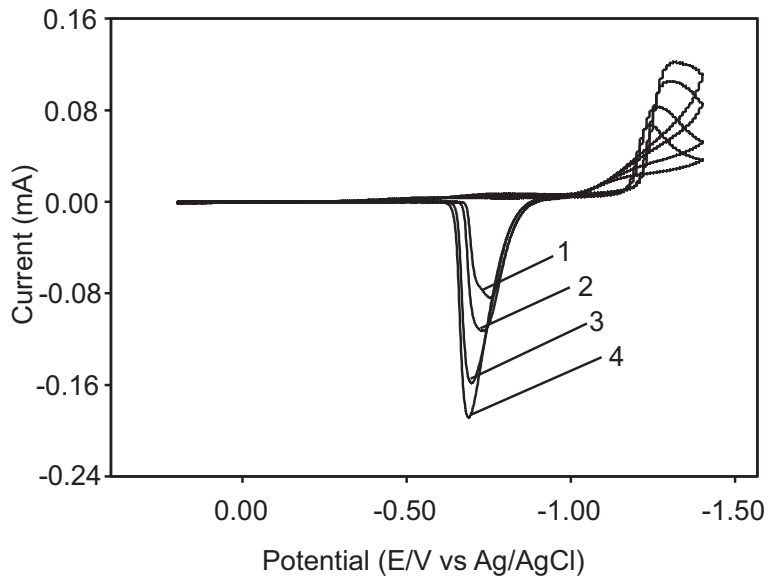

Fig. 8. $\mathrm{CVs}$ of $3 \mathrm{mM} \mathrm{ZnCl} \mathrm{Zn}_{2}$ with $3 \mathrm{mM}$ Asp in $0.1 \mathrm{M} \mathrm{NaClO}_{4}$ at different scan rates (1) 50, , (2) 100 , (3) 200 and (4) $300 \mathrm{~V} / \mathrm{s}$.

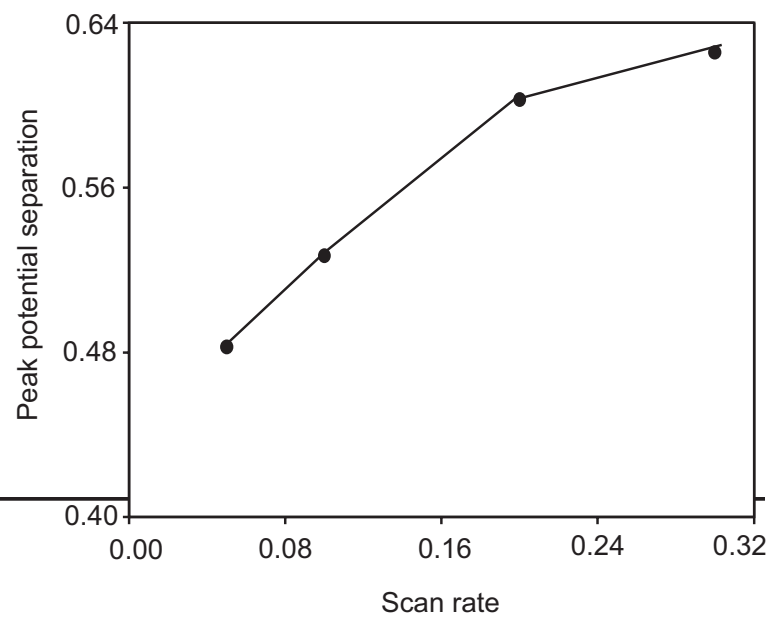

Fig. 9. Variation of peak potential separation with scan rate.

Table 2. Current-potential data, peak potential separation, peak current ratio of the voltammograms of $3 \mathrm{mM}$ $\mathrm{ZnCl}_{2}$ with $3 \mathrm{mM}$ Asp in $0.1 \mathrm{M} \mathrm{NaClO}_{4}$ at different scan rates

\begin{tabular}{|c|c|c|c|c|c|c|c|}
\hline $\begin{array}{l}\text { Scan rate } \\
\mathrm{V} / \mathrm{s}\end{array}$ & $\begin{array}{l}\text { SQRT of } \\
\text { scan rate } \\
\mathrm{v}^{1 / 2}\end{array}$ & $\begin{array}{l}\text { Anodic peak } \\
\text { potential } \\
\text { E }_{\text {pa Volt }} \\
(-)\end{array}$ & $\begin{array}{l}\text { Cathodic peak } \\
\text { potential } \\
\mathrm{E}_{\mathrm{pc}} \text { Volt } \\
(-)\end{array}$ & $\begin{array}{l}\text { Anodic peak } \\
\text { current } \\
\mathrm{i}_{\mathrm{pa}} \mathrm{mA} \\
(-)\end{array}$ & $\begin{array}{l}\text { Cathodic peak } \\
\text { current } \\
\mathrm{i}_{\mathrm{pc}} \mathrm{mA} \\
(+)\end{array}$ & $\begin{array}{l}\text { Peak potential } \\
\text { separation } \\
\Delta \mathrm{E} \text { Volt }\end{array}$ & $\begin{array}{l}\text { Peak current } \\
\text { ratio } \\
\mathrm{i}_{\mathrm{pa}} / \mathrm{i}_{\mathrm{pc}}\end{array}$ \\
\hline 0.050 & 0.2236 & 0.7564 & 1.2390 & 0.0830 & 0.0682 & 0.4826 & 1.2170 \\
\hline 0.100 & 0.3162 & 0.7341 & 1.2610 & 0.1130 & 0.0867 & 0.5269 & 1.3033 \\
\hline 0.200 & 0.4472 & 0.6983 & 1.3010 & 0.1570 & 0.1070 & 0.6027 & 1.4673 \\
\hline 0.300 & 0.5477 & 0.6894 & 1.3150 & 0.1880 & 0.1267 & 0.6256 & 1.4838 \\
\hline
\end{tabular}


The nature of Fig. 10 and 11 further confirms the adsorption of $\mathrm{Zn}$-aspartic acid at the GC electrode surface (Christian, 2004; Bard and Faulkner, 1980; Wopschall and Shain, 1967a and b).

A plot of $\log$ i vs $\log v$ (Fig. 12) is linear, again indicating that the process is diffusion controlled (Salimi and Ghadermazi, 2002; Mascus et al., 1996).

Effect of supporting electrolyte. The CVs of coordinated $\mathrm{Zn}$ (II) in three different electrolytes namely $0.1 \mathrm{M}$ $\mathrm{KCl}, 0.1 \mathrm{M} \mathrm{NaClO}_{4}$, and acetate buffer of $\mathrm{pH} 5.50$ at $200 \mathrm{~m} / \mathrm{Vs}$ are shown in Fig. 13, which indicates that the supporting electrolytes have very poor effect on the redox behaviour of $\mathrm{Zn}$-system. The pattern of the CVs also indicate that the mechanism of interaction between metal and ligand in all the media are more or less similar.

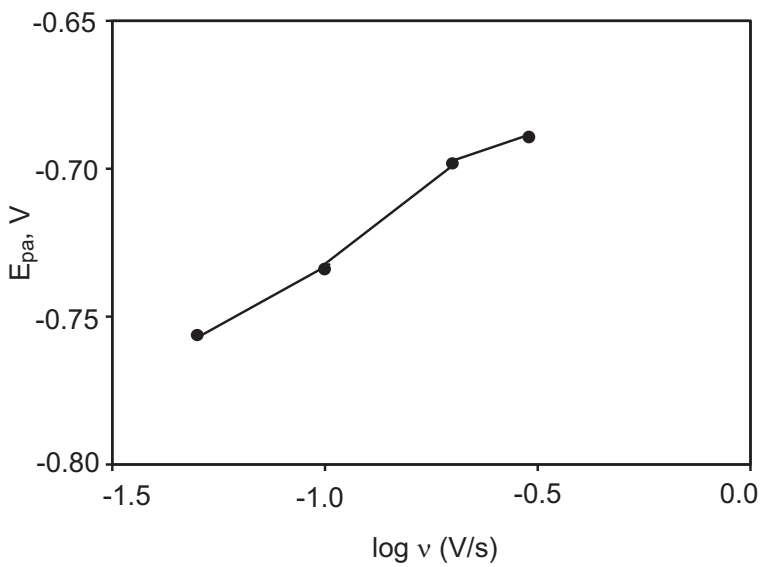

Fig. 10. Plot of peak potential vs $\log v$ for the oxidation peak.

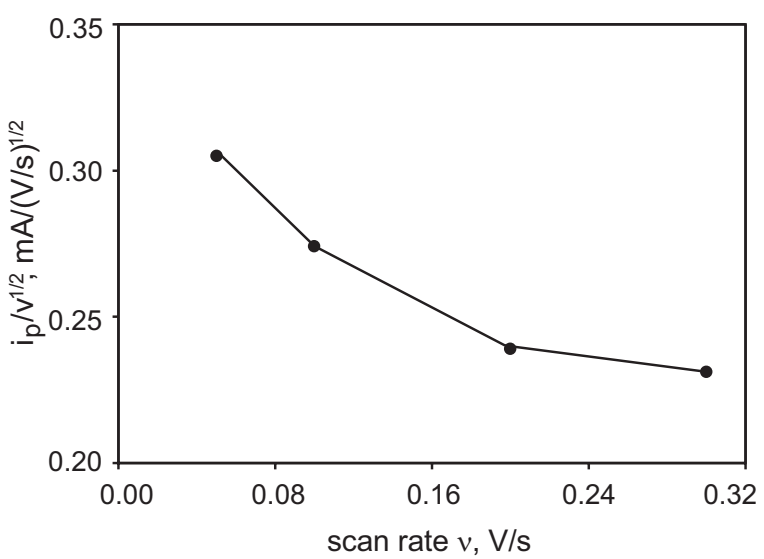

Fig. 11. Variation peak current function $\left(\mathrm{i}_{\mathrm{p}} / \mathrm{v}^{1 / 2}\right)$ with scan rate.
Effect of pH. Cyclic voltammograms of $3 \mathrm{mM} \mathrm{ZnCl}_{2}$ with $3 \mathrm{mM}$ Asp in acetate buffer of $\mathrm{pH} 4.06,4.75,5.24$ and 5.50 at $200 \mathrm{~m} / \mathrm{Vs}$ are shown in Fig. 14. At pH 5.50, two well-defined anodic and cathodic peaks are observed. At pH 4.75 and 5.24 one pair of anodic peaks and a cathodic peak are observed which may be due to intermediate formation or to an electrochemical reaction coupled with a chemical reaction. At lower $\mathrm{pH}$ (4.06) no cathodic peak was observed but only an anodic peak. Fig. 15 shows the change of extent of interaction between metal and ligand and also shows that at $\mathrm{pH} 4.75$ the peak current is minimum and maximum at $\mathrm{pH}$ 5.50.

Charge transfer rate constant. For an irreversible system, the rate constant, $\mathrm{k}_{\mathrm{f}}$ for the charge transfer process can be calculated by using the equations (1)

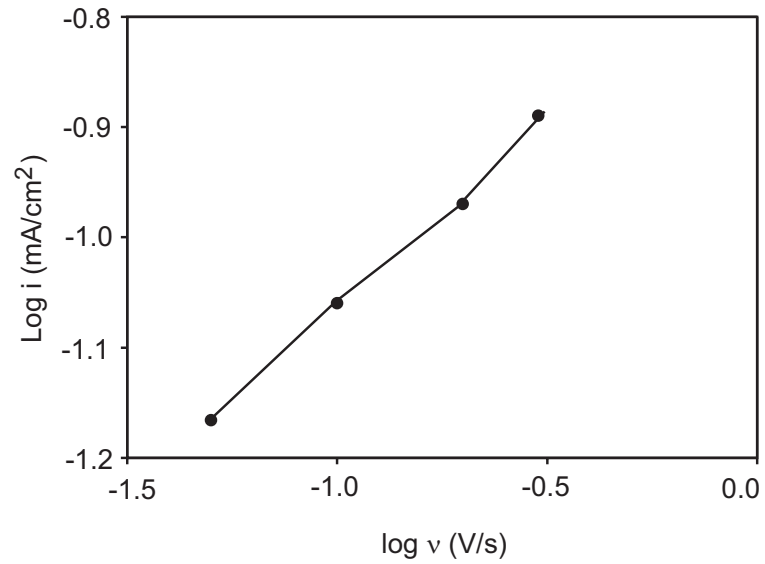

Fig. 12. Plot of $\log \mathrm{i}$ vs $\log v$ for $3 \mathrm{mM} \mathrm{ZnCl}_{2}$ with $3 \mathrm{mM}$ Asp in $0.1 \mathrm{M} \mathrm{NaClO}_{4}$.

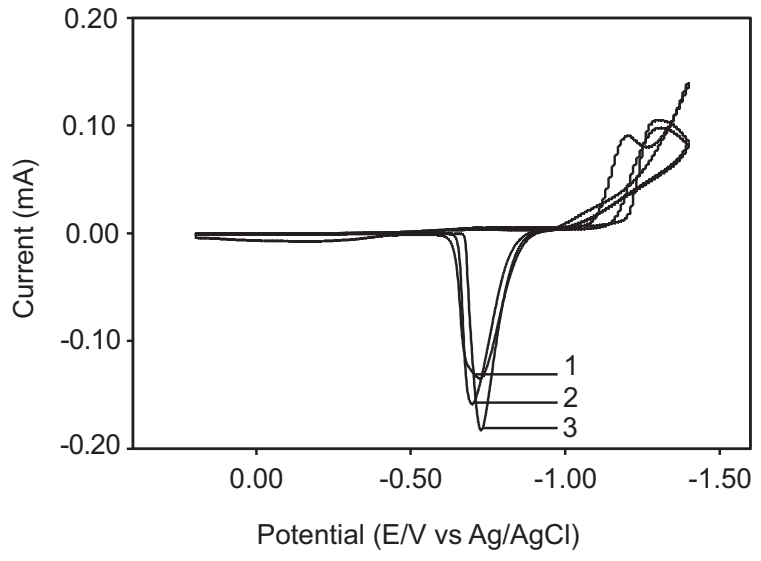

Fig. 13. $\mathrm{CVs}$ of $3 \mathrm{mM} \mathrm{ZnCl}_{2}$ with $3 \mathrm{mM}$ Asp in (1) $\mathrm{KCl}$, (2) $\mathrm{NaClO}_{4}$ and (3) acetate buffer of $\mathrm{pH} 5.50$ at $200 \mathrm{mV} / \mathrm{s}$. 
(Matsuda and Ayabe, 1955), (2) (Nichololson and Shain, 1965) and (3) as given below:

$E_{p c}=E_{1 / 2}-b\left(0.52-1 / 2 \log b / D-\log k_{f}+1 / 2 \log v\right)$

where, $\mathrm{E}_{\mathrm{pc}}=$ cathodic peak potential, volt $(\mathrm{V}), \mathrm{E}_{1 / 2}=$ half wave potential $(\mathrm{V}), \mathrm{D}=$ diffusion coefficient $\left(\mathrm{cm}^{2} / \mathrm{s}\right)$, $\mathrm{b}=$ Tafel slope $=2.303 \mathrm{RT} / \alpha \mathrm{N}_{\mathrm{a}} \mathrm{F} ; \alpha=$ transfer coefficient, $\mathrm{N}_{\mathrm{a}}=$ number of electrons involved in the rate determining step, $\mathrm{R}=$ molar gas constant $=8.314$ joul $/ \mathrm{K} / \mathrm{mol}, \mathrm{T}=$ temperature $\left({ }^{\circ} \mathrm{K}\right), v=$ scan rate $(\mathrm{V} / \mathrm{s})$ and $\mathrm{k}_{\mathrm{f}}=$ charge transfer rate constant $(\mathrm{cm} / \mathrm{s})$.

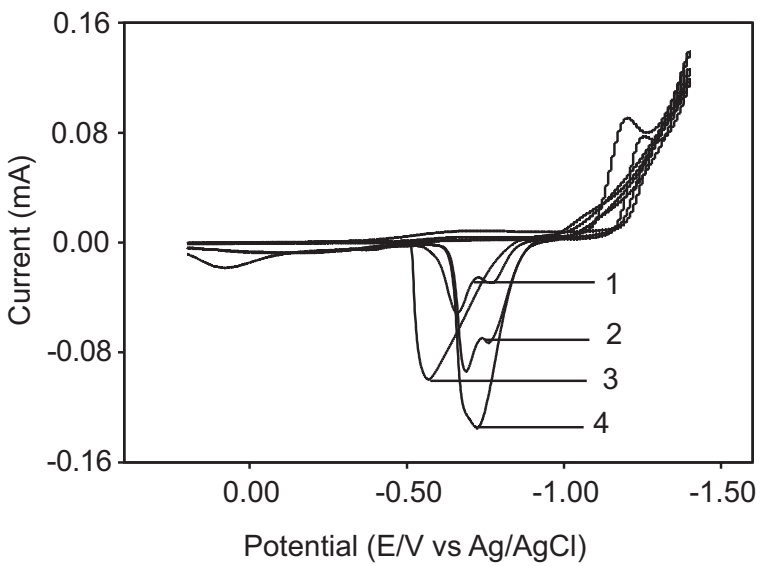

Fig. 14. CVs of $3 \mathrm{mM} \mathrm{ZnCl}_{2}$ with $3 \mathrm{mM}$ Asp in acetate buffer of $\mathrm{pH} 4.06,4.75,5.24$ and 5.50 at $200 \mathrm{mV} / \mathrm{s}$. and $\left(\mathrm{E}_{\mathrm{p}}\right)_{2}-\left(\mathrm{E}_{\mathrm{p}}\right)_{1}=\left(2.303 \mathrm{RT} / \alpha \mathrm{N}_{\mathrm{a}} \mathrm{F}\right) \log v\left(v_{1} / v_{2}\right)$ where, $\left(\mathrm{E}_{\mathrm{p}}\right)_{2}$ and $(\mathrm{Ep})_{1}$ are the peak potentials at scan rates $v_{2}$ and $v_{1}$, respectively. The diffusion coefficient of a system can be calculated by using the following equation:

$\mathrm{i}_{\mathrm{pc}}=2.99 \times 10^{5} \mathrm{n}\left(\alpha \mathrm{N}_{\mathrm{a}}\right)^{1 / 2} \mathrm{~A} \mathrm{D}^{1 / 2} \mathrm{C} \mathrm{v}^{1 / 2}$

where, $\mathrm{i}_{\mathrm{pc}}=$ cathodic peak current (amperes), $\mathrm{n}=$ total number of electrons involved in the reaction, $\alpha=$ transfer coefficient, $\mathrm{N}_{\mathrm{a}}=$ number of electrons involved in the

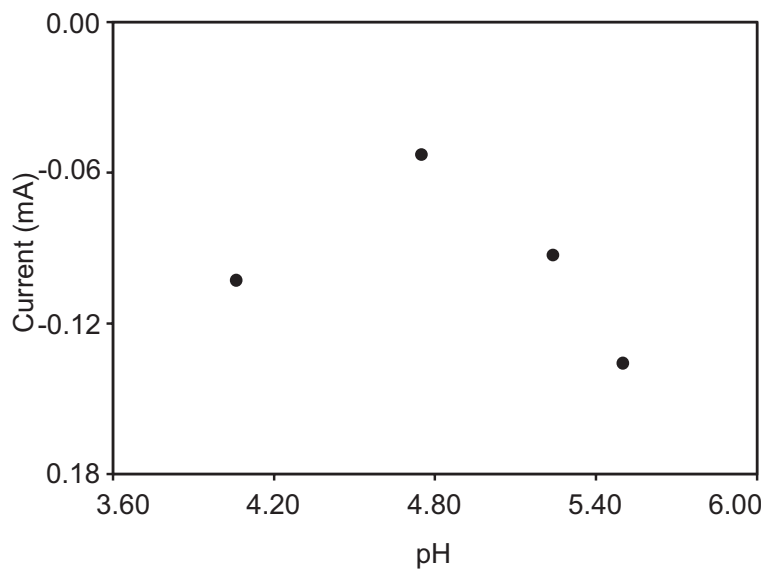

Fig. 15. Variation of anodic peak current with $\mathrm{pH}$ for $3 \mathrm{mM} \mathrm{ZnCl} 2$ with $3 \mathrm{mM}$ aspartic acid in acetate buffer.

Table 3. Current-potential data, Tafel slope b, diffusion coefficient, D and the charge-transfer rate constant, $k_{f}$ calculated from the voltammograms of free $\mathrm{Zn}$ (II) and $\mathrm{Zn}$ (II)-Asp interaction on GCE at ambient temperature

\begin{tabular}{|c|c|c|c|c|c|c|c|}
\hline Sample ID & $\begin{array}{l}\text { Scan rate } \\
v \\
\mathrm{~V} / \mathrm{s}\end{array}$ & $\begin{array}{l}\text { Cath }^{c} \text { peak } \\
\text { poten } \\
E_{p c}(V) \\
(-)\end{array}$ & $\begin{array}{l}\text { Cath }^{c} \text { peak } \\
\text { current } \\
\mathrm{i}_{\mathrm{pc}}(\mathrm{mA})\end{array}$ & $\begin{array}{l}\text { Tafel slope } \\
b=2.303 \\
\text { RT / } \alpha N_{a} F\end{array}$ & $\begin{array}{l}\operatorname{Diff}^{\mathrm{n}} \text { coeff. } \\
\mathrm{D} \times 10^{5} \\
\mathrm{~cm}^{-2} / \mathrm{s}\end{array}$ & $\begin{array}{l}-\log k_{f} \\
(\mathrm{~cm} / \mathrm{s})\end{array}$ & $\begin{array}{l}\text { Charge transfer } \\
\text { rate constant } \\
k_{f} \times 10^{-3} \\
(\mathrm{~cm} / \mathrm{s})\end{array}$ \\
\hline $\mathrm{Zn}(\mathrm{II})$ in $\mathrm{KCl}$ & $\begin{array}{l}(v)_{1}=0.050 \\
(v)_{2}=0.100\end{array}$ & $\begin{array}{l}1.0870 \\
1.1050\end{array}$ & $\begin{array}{l}0.0967 \\
0.1306\end{array}$ & 0.1377321 & 9.875830 & 1.858287 & 13.858 \\
\hline $\begin{array}{l}\mathrm{Zn}(\mathrm{II}) \text { in } \\
\mathrm{NaClO}_{4}\end{array}$ & $\begin{array}{l}(v)_{1}=0.050 \\
(v)_{2}=0.100\end{array}$ & $\begin{array}{l}1.0510 \\
1.0640\end{array}$ & $\begin{array}{l}0.1182 \\
0.1464\end{array}$ & 0.0994732 & 8.962733 & 1.808698 & 15.535 \\
\hline $\begin{array}{l}\mathrm{Zn}(\mathrm{II})-\mathrm{Asp} \\
\text { in } \mathrm{KCl}\end{array}$ & $\begin{array}{l}(v)_{1}=0.050 \\
(v)_{2}=0.100\end{array}$ & $\begin{array}{l}1.2250 \\
1.2610\end{array}$ & $\begin{array}{l}0.0667 \\
0.0800\end{array}$ & 0.2754641 & 7.411348 & 2.071102 & 8.489 \\
\hline $\begin{array}{l}\mathrm{Zn}(\mathrm{II})-\mathrm{Asp} \\
\text { in } \mathrm{NaClO}_{4}\end{array}$ & $\begin{array}{l}(v)_{1}=0.050 \\
(v)_{2}=0.100 \\
(v)_{2}=0.100\end{array}$ & $\begin{array}{l}1.2390 \\
1.2610 \\
1.2160\end{array}$ & $\begin{array}{l}0.0682 \\
0.0867 \\
0.0633\end{array}$ & 0.1683397 & 5.319575 & 2.036179 & 9.201 \\
\hline
\end{tabular}

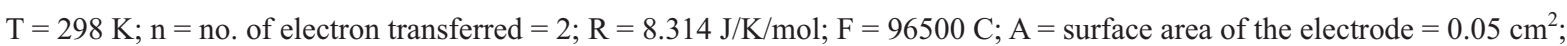
Concentration $=3.0 \mathrm{mM}$. 
rate determining step, $\mathrm{A}=$ area of the electrode $\left(\mathrm{cm}^{2}\right)$, $\mathrm{C}=$ concentration of the electroactive species $(\mathrm{mol} / \mathrm{L})$, $v=$ scan rate $(\mathrm{V} / \mathrm{s}), \mathrm{D}=$ diffusion coefficient $\left(\mathrm{cm}^{2} / \mathrm{s}\right)$.

In the present study, the value of $b$, the diffusion coefficient, D and the heterogeneous charge transfer rate constant, $\mathrm{k}_{\mathrm{f}}$ values for the electro active species were calculated from the experimental data using software and reported in Table 3.

To calculate the heterogeneous charge transfer rate constant, $\mathrm{k}_{\mathrm{f}}$ the current - potential data obtained from the cyclic voltammograms of free $\mathrm{Zn}$ (II) and $\mathrm{Zn}$ (II)Asp interaction in $0.1 \mathrm{M} \mathrm{KCl}$ and $0.1 \mathrm{M} \mathrm{NaClO}_{4}$ at 50 $\mathrm{mV} / \mathrm{s}$ and $100 \mathrm{mV} / \mathrm{s}$ are used.

The heterogeneous charge transfer rate constant, $\mathrm{k}_{\mathrm{f}}$ for free $\mathrm{Zn}$ (II) system is greater than that in the metal-Asp system at $298 \mathrm{~K}$ temperature which may be due to the complexation of $\mathrm{Zn}(\mathrm{II})$ with Aspartic acid.

The CVs of $\mathrm{Zn}(\mathrm{II}) / \mathrm{Zn}(0)$ system shows one pair of cathodic and anodic peaks for the following charge transfer process.

$$
\begin{aligned}
& \mathrm{Zn}(\mathrm{II})+2 \mathrm{e}^{-} \rightarrow \mathrm{Zn}(0) \\
& \mathrm{Zn}(0)-2 \mathrm{e}^{-} \rightarrow \mathrm{Zn}(\mathrm{II})
\end{aligned}
$$

The results show that interaction between $\mathrm{Zn}$ and Asp has been taken place and the redox process for both coordinated and uncoordinated $\mathrm{Zn}(\mathrm{II}) / \mathrm{Zn}(0)$ system in all electrolytes is diffusion controlled. The values of peak current and peak potential separation suggest that the redox processes are quasi-reversible. In presence of acetate buffer, the redox systems show almost similar behaviour.

\section{References}

Bard, A.J., Faulkner, L.R. 1980. Electrochemical Methods, Fundamentals and Applications, 228 pp., John Wiley and Sons, New York, USA.

Christian, G.D. 2004. Analytical Chemistry, $6^{\text {th }}$ edition, John Wiley and Sons. Inc., USA.

Cousins, R.I. 1996. Zinc. In: Present Knowledge in Nutrition, E. E. Zeigler, L. J. Filer (eds.), ILSI Press, Washington DC., USA.

Ismat-Ara, Shaikh, A.A., Ehsan, M.Q., Khan, A.H. 2003. Electrochemical behaviour of copper-aspartic acid complex at glassy carbon electrode. Journal of Saudi Chemical Society, 7: 129-138.

Kabir, M.K., Ehsan, M.Q., Khan, A.H. 2002. Anodic stripping voltammetry at thin mercury film electrode for trace analysis in environmental and biological studies. Journal of Bangladesh Chemical Society, 15: 1-12.

Khan, A.H., Ahmed, M.G., Akhter, F. 1999. Interaction between metal ions and nalidixic acid-a potentiometric study. Journal of Bangladesh Chemical Society, 12: 45-51.

Mascus, M., Pariente, F., Wu, Q., Toffanin, A., Shapleigh, J.P., Abruna, H.D. 1996. Electrocatalytic reduction of nitric oxide at electrodes modified with electropolymerised films and their application cellular NO determination. Analytical Chemistry, 68: $3128-3134$.

Matsuda, H., Ayabe, Y. 1955. Zur theorie der randlesSvcikschen kathodenstrahl-polarographie. Zeitschrift fur Elektrochemie, Berichte der Bunsengesellscaft fur Physikalische Chemie, 59: 494-503.

Nabi, E., Haider, S.Z., Khan, A.H., Kibria, A.K.M.F. 1999. Stripping voltammetric studies of copperglutathion complexation in sea water. Journal of Bangladesh Academy of Sciences, 23: 207-217.

Naseem, A.H.M., Shaikh, A.A., Ehsan, M.Q. 2008. Cyclic voltammetric study of the redox behaviour of $\mathrm{Fe}(\mathrm{II}), \mathrm{Fe}$ (III) systems forming during the oxidation of $\mathrm{Fe}$ (II) complexes with saccharin and with saccharin and 1,10-phenanthroline. Russian Journal of Electrochemistry, 44: 1403-1408.

Nelson, D.L., Cox, M.M., Lehninger. 2000. Principles of Biochemistry, $3^{\text {rd }}$ edition, Worth Publishing, New York, USA.

Nichololson, R.S., Shain, I. 1965. Theory of stationary electrode polarography, single scan and cyclic methods applied to reversible, irreversible and kinetic systems. Analytical Chemistry, 36: 706-723.

Rahman, L.N., Ehsan, M.Q., Khan, A.H. 1998a. Copper glutathion interactions for complexation and speciation studies at thin mercury film electrode in Artificial sea water. Dhaka University Journal of Science, 46: 223-235.

Rahman, L.N., Nabi, E., Khan, A.H. 1998b. Coppercysteine and cadmium-cystein interactions for complexation and speciation studies with thin mercury film electrode in Artificial sea water. Dhaka University Journal of Science, 46: 237-246.

Rahman, M.S., Naseem, A.H.M., Bakshi, P.K., Ehsan, M.Q. 2007. Studies on redox behaviour of $\mathrm{Mn}$ (II)/ $\mathrm{Mn}(\mathrm{IV})$ system and interaction of $\mathrm{Mn}$ (II) with aspartic acid. Journal of Saudi Chemical Society, 11: $277-286$.

Rossiter, B.W., Hamilton, J.F. 1986. Physical Methods of Chemistry, Electrochemical Methods, Chapter 1, 
vol. 2, pp. 273-345, John Wiley and Sons. Inc., USA.

Salimi, A., Ghadermazi, M. 2002. Electroanalytic reduction of dioxygen on a glassy carbon electrode modified with adsorbed cobaloxime complex. Analytical Sciences, 17: 1165-1170.

Shaikh, A.A., Marzina, B., Khan, A.H., Ehsan, M.Q. 2006. The cyclic voltammetric studies of the redox behaviour of Iron(III) vitamin B6 complex at carbon paste electrode. Russian Journal of Electrochemistry, 42: 620-625.

Shaikh, A.A., Afzal, S.N., Ehsan, M.Q., Khan, A.H. 2005. Electrochemical study on redox reaction of iodide and bromide in presence of benzoylacetone at carbon electrodes. Journal of Saudi Chemical Society, 9: 279-286.

Wopschall, R.H., Shain, I. 1967a. Effect of adsorption of electroactive species in stationary electrode polarography. Analytical Chemistry, 39: 1514-1527. Wopschall, R.H., Shain, I. 1967b. Adsorption effect in stationary electrode polarography with a chemical reaction following charge transfer. Analytical Chemistry, 39: 1535-1542.

Zhang, J., Anson, F.C. 1992. Voltammetry and in situ Fourier transform IR spectroscopy of two anthraquinone disulfonates adsorbed on graphite electrodes. Journal of Electrical and Analytical Chemistry, 331: 945-957. 